EDYTA WOLTER

Wydział Nauk Pedagogicznych

Uniwersytet Kardynała Stefana Wyszyńskiego w Warszawie

ORCID ID: http://orcid.org/oooo-ooo1-9895-6462
Forum Pedagogiczne 9 (2019) 1

Wpłynęło: 1.12.2018

Zatwierdzono do druku: 24.04.2019 DOI: $10.21697 / f p .2019 .1 .12$

\title{
OCHRONA PRZYRODY OJCZYSTEJ W DRUGIEJ RZECZYPOSPOLITEJ - EDUKACYJNE IMPLIKACJE MIESIĘCZNIKA „PRZYRODA I TECHNIKA”
}

\begin{abstract}
Streszczenie: Celem artykułu jest wyjaśnienie dziedzictwa kultury na przykładzie wychowania do ochrony przyrody w Polsce w okresie dwudziestolecia międzywojennego (1918-1939). Podstawę źródłową stanowi czasopismo „Przyroda i Technika”, wydawane przez Polskie Towarzystwo Przyrodników im. M. Kopernika w latach 1922-1939. W artykule uzasadniono znaczenie procesu wychowania do ochrony przyrody społeczeństwa polskiego na podstawie wybranych artykułów i konkursów edukacyjnych, wystaw poświęconych problematyce opieki nad zwierzętami, a także popularyzacji książek oraz czasopism poświęconych ochronie przyrody.
\end{abstract}

Słowa kluczowe: historia edukacji; „Przyroda i Technika”; ochrona przyrody; wychowanie do postaw ekologicznych.

\section{Wstęp}

Miesięcznik „Przyroda i Technika” (poświęcony naukom przyrodniczym i ich zastosowaniu oraz rozwojowi przemysłu i rolnictwa) był wydawany przez Polskie Towarzystwo Przyrodników im. M. Kopernika ${ }^{1}$ nakładem Książnicy Polskiej Towarzystwa Nauczycieli Szkół Wyższych przy dofinansowaniu Wydziału Nauki

1 Wiosną 1938 roku do nr 3 „Przyrody i Techniki” z 1928 roku dołączono luźną ulotkę, z której treści wynika, że przewodniczącym Polskiego Towarzystwa Przyrodników im. M. Kopernika (które co podkreślono, wstępuje w 53. rok swego istnienia/działalności) jest dr J. Tokarski, sekretarzem jest dr M. Kamieński. Podano także adresy oddziałów Towarzystwa w Bydgoszczy (ul. Ossolińskich 4), Katowicach (Referat Szkolny Województwa), Krakowie (ul. Smoleńska 23), Lwowie (ul. św. Mikołaja 4), Poznaniu (ul. Słowackiego 4), Sosnowcu (ul. Czeladzka 2), Warszawie (ul. Chałubińskiego 5), Wilnie (ul. Słowackiego 9). Zob. „Przyroda i Technika” (Miesięcznik poświęcony naukom przyrodniczym i ich zastosowaniu. Wydawany przez Polskie Towarzystwo Przyrodników im. M. Kopernika), 1928 (rocznik 7), (marzec), ulotka w załączeniu. 
Ministerstwa Wyznań Religijnych i Oświecenia Publicznego, następnie Książnicy Atlas Zjednoczonych Zakładów Kartograficznych i Wydawniczych Towarzystwa Nauczycieli Szkół Średnich i Wyższych Spółki Akcyjnej. Redaktorem naczelnym miesięcznika został dr Benedykt Fuliński - profesor Politechniki Lwowskiej, członek Zarządu Głównego Polskiego Towarzystwa Przyrodników im. M. Kopernika. Od stycznia 1926 roku redaktorem naczelnym był dr Marian Koczwara. Komitet redakcyjny tworzyli członkowie Polskiego Towarzystwa Przyrodników im. M. Kopernika: prof. Jan Nowak i prof. Władysław Szafer (oddział krakowski), prof. Jerzy Wąsowicz i prof. Fortunat Stroński (oddział lwowski), prof. Edward Lubicz Niezabitowski i prof. Wilhelm Friedberg (oddział poznański), prof. Jan Lewiński i dr Piotr Słonimski (oddział warszawski) ${ }^{2}$.

W pierwszym numerze analizowanego periodyku Stefan Niementowski przewodniczący Zarządu Głównego Polskiego Towarzystwa Przyrodników im. M. Kopernika poinformował czytelników, że „Przyroda i Technika” jest miesięcznikiem wydawanym od października 1922 roku w nakładzie 30 tys. egzemplarzy (z wyjątkiem lipca i sierpnia), w sytuacji, „gdy zawiodły starania o wydawanie „Wszechświata” (Niementowski 1922/1, s. 1-3). Zapowiedziano, że na łamach miesięcznika będzie omawiana problematyka dotycząca fizjografii ziem polskich, krajoznawstwa oraz ochrony przyrody. W 1931 roku redaktorem miesięcznika została dr Anna d'Abancourt-Koczwarowa. Komitet redakcyjny stanowili: prof. E. Romer (przewodniczący), prof. J. Siedlecki (wiceprzewodniczący). Zmieniono także podtytuł czasopisma ${ }^{3}$.

Wśród wielu działów miesięcznika można wymienić: Artykuły, Sprawy bieżace, Postępy i zdobycze wiedzy, Rzeczy ciekawe, Co się dzieje w Polsce, Poradnik przyrodnika-fotografa, Ruch organizacyjny, Książki nadesłane. Prezentowano w nich nie tylko problematykę dotyczącą ochrony przyrody, lecz także: antropologii, astronomii, botaniki, budownictwa, chemii (organicznej, nieorganicznej), technologii, fizjologii, fizyki, geografii, podróży, geologii i paleontologii, górnictwa i hutnictwa, hodowli, komunikacji, lotnictwa, leśnictwa i łowiectwa, mechaniki i maszynoznawstwa, medycyny, higieny, farmakologii, meteorologii, klimatologii, optyki, kina, fotografii, pirotechniki, prehistorii, ruchu naukowego i organizacyjnego, surowców (i surowców zastępczych), telekomunikacji, towaroznawstwa, wewnętrznego wydzielania i witamin, zoologii, zwalczania szkodników.

2 Adres redakcji i administracji „Przyrody i Techniki”: Książnica Atlas, Lwów ul. Czarnieckiego 12. Zob. „Przyroda i Technika” (Miesięcznik poświęcony naukom przyrodniczym i ich zastosowaniu. Wydawany przez Polskie Towarzystwo Przyrodników im. M. Kopernika), 1928 (rocznik 7), z. 8 (październik), wewnętrzna strona okładki.

3 „Przyroda i Technika” (Czasopismo poświęcone popularyzacji nauk przyrodniczych i technicznych. Wychodzi raz na miesiąc z wyjątkiem lipca i sierpnia), 1931 (rocznik 10), z. 1 (styczeń), okładka. 
Na łamach miesięcznika (w dziale Sprawy bieżące) pisano o najnowszych projektach rozporządzeń prawnych dotyczących roślin i zwierząt, aktach normatywnych w zakresie ochrony przyrody, tworzonych w celu zachowania równowagi w przyrodzie, o wdrożeniu postulatów ochrony przyrody w zakresie łowienia zwierząt, o wprowadzeniu zakazu polowania na żubry, bobry, kozice, świstaki, czarne bociany, samice niedźwiedzi, łosie, jelenie, daniele, sarny, głuszce oraz na cietrzewie (w Polsce zachodniej i południowej). Informowano czytelników o projektach rozporządzeń dotyczących ochrony fauny polskiej.

\section{Edukacyjne implikacje ochrony przyrody}

W periodyku wyjaśniano znaczenie ochrony przyrody (Lindeman 1937/3, s. 139-140), opisywano rozwój tej idei (Wodziczko 1935/4, s. 145-148). Pisano o doniosłości poznania i ochrony „swojszczyzny”, zapobiegania wycinaniu/niszczeniu lasów, osuszaniu torfowisk (Krzemieniewski 1922/1, s. 23-27), nadmiernej eksploatacji bogactw naturalnych (Pazdro 1925/10, s. 441-448). Podejmowano tematy z życia przyrody w siedlisku lasu jako wysoko zorganizowanej całości przyrodniczej, która powinna pozostawać $\mathrm{w}$ pewnych stosunkach proporcji zapewniającej lasowi harmonię i trwałość istnienia (Jarmolińska 1935/6, s. 1-8; Sokołowski 1937/6, s. 321-334; Paczoski 1937/8, s. 449) oraz informowano o ginących gatunkach żubra (Kuntze 1935/18, s. 448-455), przedstawiono dane liczbowe dotyczące populacji żubrów w Białowieży, pisano o ochronie starych drzew w Polsce.

Profesor Seweryn Krzemieniewski uświadamiał czytelnikom zagrożenia spowodowane spustoszeniem przyrody podczas pierwszej wojny światowej. Opublikował artykuły o ponadmaterialnej wartości piękna Puszczy Białowieskiej oraz o znaczeniu szeroko pojętego (obejmującego różnorodne kręgi społeczne) procesu edukacji do czynnych postaw ekologicznych: „aby ochrona zabytków naszej przyrody i krajobrazu rodzinnego mogła być skuteczną, konieczne jest współdziałanie społeczeństwa i rządu. [...] Najwięcej ma tu do spełnienia szkoła. Nauczyciel nie powinien omijać żadnej sposobności, aby w dziecko polskie wszczepiać zamiłowanie do ojczystej przyrody. Środków do tego jest wiele - cenny materiał daje nasza poezja i powieść współczesna. [...] W pobliżu każdej szkoły można odnaleźć przedmiot godny uwagi i poszanowania, czy będzie to głaz, czy piętrząca się skała, czy drzewo. [...] W szkole średniej należy pogłębiać zrozumienie dla rzadszych zwierząt i roślin, przestrzegając przed ich tępieniem" (Krzemieniewski 1922/2, s. 95-96).

W tym kontekście Benedykt Fuliński opisał działalność prof. Mariana Raciborskiego, który szerzył/popularyzował wiedzę o ochronie przyrody, nakłaniał do organizowania lokalnych (prowincjonalnych) muzeów przyrodniczo-krajoznawczych (por. Fuliński 1923/4, s. 205-210). W miesięczniku napisano o działalności Państwowej Komisji Ochrony Przyrody po reorganizacji Państwowej Rady Ochrony Przyrody w zakresie ochrony przyrody w Tatrach, tzw. zabytków przyrody, zwłaszcza przez nauczycieli i młodzież, którą należy zainteresować 
ideą ochrony przyrody, zakładaniem lokalnych (prowincjonalnych) kół ochrony przyrody, miłośników „swojszczyzny”. Informowano także o tematyce obrad Państwowej Rady Ochrony Przyrody (w sali konferencyjnej Ministerstwa Wyznań Religijnych i Oświecenia Publicznego, którym przewodniczył prof. Władysław Szafer) z przedstawicielami Ministerstwa Spraw Wewnętrznych, Ministerstwa Rolnictwa i Reform Rolnych, Ministerstwa Spraw Zagranicznych, Ministerstwa Spraw Wojskowych, Ministerstwa Komunikacji, Ministerstwa Przemysłu i Handlu, Ministerstwa Poczt i Telegrafów, Ministerstwa Wyznań Religijnych i Oświecenia Publicznego oraz delegatami licznych towarzystw naukowych - podczas których dyskutowano o pilnej potrzebie realizowania problematyki ochrony przyrody w szkołach powszechnych, średnich ogólnokształcących, średnich licealnych i wyższych (por. Ruch naukowy 1933/4, s. 186-187).

Na łamach „Przyrody i Techniki” instruowano, jak należy zachowywać się podczas wycieczek na obszarach chronionych. Egzemplifikację stanowią wskazówki dla zwiedzających Park Narodowy im. Stefana Żeromskiego, którym zakazano wjeżdżać na ten obszar rowerem, motocyklem, samochodem. Wstęp (płatny) dozwolony był (za pozwoleniem kierownictwa obszaru chronionego) tylko dla pieszych po wyznaczonych do tego celu ścieżkach, szlakach. Obozowanie/biwakowanie było możliwe tylko w miejscach wyznaczonych. Na terenie Parku Narodowego im. Stefana Żeromskiego zabroniono zrywania kwiatów, łowienia i płoszenia zwierząt, kąpieli, plażowania, hałaśliwego zachowania się, zaśmiecania, strzelania (por. Co się dzieje..., 1933/8, s. 367-368). Napisano o pilnej konieczności ochrony świstaka przed zagładą ( $Z$ ochrony przyrody 1923/5, s. 297-302) oraz o innych ginących gatunkach zwierząt: żubra/Bison bonasus L., bizona/Bison bison L., bobra/Castor fiber L., wydry morskiej/Latax lustris L. (Dunajewski 1930/8, s. 337-347), żółwia/Emys orbicularis $L$., a także o ochronie polskich lasów przed nadmierną ich eksploatacją (zwłaszcza w Tatrach), ochronie drzewa cis (Ginace drzewo 1924/3-4, s. 243-246), jak również o ochronie żubrów w Puszczy Białowieskiej.

Popularyzowano wiedzę o rezerwatach flory stepowej na Podolu, takich jak: Rezerwat w Obiżowej pod Zaleszczykami (własność prywatna baronowej Stelli Turnauowej), Rezerwat na ścianie Hłody w Kołodróbce (rezerwat prywatny Edwarda Sidorowicza), Rezerwat w Oleksińcach nad Dniestrem (własność inż. Antoniego Gromnickiego). Systematycznie pisano na temat polskich obszarów chronionych i pilnej konieczności ich zakładania. Wyjaśniono czytelnikom, że skarb państwa zakupił na cele Tatrzańskiego Parku Narodowego tereny tatrzańskie (dobra Murzasichle). Napisano także o negatywnym wpływie działalności człowieka w środowisku przyrody (Kuntze 1926/10, s. 451-458), zanieczyszczaniu powietrza w miastach przez dym węglowy (Jaranowska 1927/9, s. 405-418) oraz o zmianach klimatu (Klimowicz 1927/9, s. 425-427). Stwierdzono, że idea ochrony przyrody coraz lepiej rozwija się w Polsce, „powoli staje się chlebem powszednim. Przyjęta zrazu nieufnie, niezrozumiana, a nawet wręcz zwalczana, zdołała w ciągu kilku lat skruszyć częściowo skorupę obojętności, z jaką ją większość społeczeństwa witała 
u jej zarania" (Ochrona przyrody w Polsce 1929/5, s. 220). Drukowano artykuły poświęcone problematyce ochrony przyrody, takie jak np. S. Kelery pt. Ochrona przyrody ze stanowiska pierwotnego i kulturalnego, w którym autor zaprezentował rys historyczny negatywnego wpływu człowieka na przyrodę. Wyjaśniano, jak należy opiekować się ptakami, zwłaszcza zimą (Keler 1934/9, s. 409-415).

Informowano czytelników o wynikach najnowszych badań naukowych w dziedzinie ochrony przyrody ${ }^{4}$, dotyczących np. dydaktyki szczegółowej ekologii zwierząt (Kuntze 1934/5, s. 197-208). Na łamach miesięcznika publikowano artykuły poświęcone problematyce ochrony roślin przed szkodnikami świata zwierzęcego (owadami) (Strawiński 1929/8, s. 348-356) oraz o dewastowaniu flory podczas nieumiejętnego zbioru roślin leczniczych (Szafer 1931/5, s. 236-239). Na łamach miesięcznika drukowano nazwy gatunków roślin chronionych na całym obszarze Rzeczypospolitej (Wodziczko 1936/3, s. 167-168).

Opisywano ponadto piękne krajobrazy, rzadko występujące zjawiska przyrody, takie jak np. zorza polarna, która stanowi jedno z najpiękniejszych zjawisk optycznych w środowisku przyrody, a także powszechnie występujące zjawiska atmosferyczne, które powstają dzięki obecności pary wodnej w powietrzu (chmury).

Wyjaśniano ekologiczne sposoby wykorzystania (wyzyskania) odpadów (Nowoczesne zużytkowanie śmieci, 1928/4, s. 184-185) w Polsce i zagranicą ${ }^{5}$. Pisano o negatywnych skutkach wyrębywania lasów, doniosłym znaczeniu ich ochrony (Dyakowski 1938/5, s. 271-277).

\section{Konkursy edukacyjne dla nauczycieli dotyczące ochrony przyrody}

Z inicjatywy Kuratorium Okręgu Szkolnego Poznańskiego wraz z rozpoczęciem roku szkolnego 1928/1929 na łamach analizowanego miesięcznika ogłoszono konkurs otwarty dla wszystkich nauczycieli zainteresowanych ochroną przyrody (nie tylko przyrodników) szkół powszechnych, średnich, seminariów nauczycielskich, którzy pracują w szkołach publicznych i prywatnych na obszarze Okręgu Szkolnego Poznańskiego na pracę pisemną pt. Jakie sa zabytki przyrody w okolicy i jak je wyzyskać w nauce szkolnej? Określono, że praca powinna stanowić szczegółowy opis zabytków przyrody znajdujących się w najbliższej okolicy lub na dobrowolnie wybranym terenie Wielkopolski. Motywowano do załączenia: map

4 Egzemplifikację stanowi artykuł: (brak nazwiska autora) Z nowszych badań nad bobrem. (1928). W: „Przyroda i Technika” (Miesięcznik poświęcony naukom przyrodniczym i ich zastosowaniu. Wydawany przez Polskie Towarzystwo Przyrodników im. M. Kopernika), 1928 (rocznik 7), z. 8 (październik), s. 368-37o.

5 Przykładem jest wprowadzenie w Niemczech papierowych opakowań do mleka w kształcie stożka, o różnej pojemności/wielkości (wykonanych z nieprzemakalnego i nieparafinowanego kartonu). Por. Rzeczy ciekawe. Papierowe flaszki do mleka. (1931). W: „Przyroda i Technika” (Czasopismo poświęcone popularyzacji nauk przyrodniczych i technicznych. Wychodzi raz na miesiąc z wyjątkiem lipca i sierpnia), 1931 (rocznik 10), z. 1 (styczeń), s. 40-42. 
opisu rozmieszczenia zabytków, zdjęć fotograficznych oraz szczegółowych szkiców, rysunków z podaniem właściciela danego zabytku, koncepcji ich zabezpieczenia przed zniszczeniem oraz planu wykorzystania opisanych zabytków w procesie nauki szkolnej. Prace pisemne należało przesłać do Komitetu Ochrony Przyrody w Poznaniu ${ }^{6}$ (w terminie do 1 listopada 1928 roku). Zaakcentowano, że chociaż ww. konkurs dotyczy tylko nauczycieli pracujących w szkołach Okręgu Szkolnego Poznańskiego, należy zachęcić kuratoria innych okręgów szkolnych do organizowania podobnych konkursów na obszarze całej Polski i motywować nauczycieli do działań aplikacyjnych w zakresie ochrony przyrody (również z wykorzystaniem formy konkursu).

\section{Popularyzacja literatury w zakresie ochrony przyrody}

W miesięczniku „Przyroda i Technika” systematycznie prezentowano zawartość wybranych czasopism poświęconych problematyce ochrony przyrody, takich jak np. rocznik „Ochrona Przyrody” (Organ Państwowej Komisji Ochrony Przyrody) (Przegląd czasopism, 1925/1, s. 92-94), na łamach którego pisano nie tylko o znaczeniu ochrony przyrody, lecz także o wadze wprowadzenia problematyki ochrony przyrody do procesu kształcenia szkolnego (Przegląd czasopism, 1925/10, s. 489). $\mathrm{Na}$ ten temat pisał Marian Sokołowski w artykule pt. O wprowadzeniu ochrony przyrody do nauczania szkolnego (1926/4, s. 190-191). W lutym 1931 roku opisano zawartość całego rocznika „Ochrona Przyrody” z 1930 roku (ss. 309). Podkreślono, że przedmiotowy rocznik należy zalecić wszystkim miłośnikom przyrody ze względu na walor poznawczy artykułów poświęconych ochronie przyrody. Stanowią one bowiem przegląd badań dotyczących ochrony przyrody. Wśród licznych autorów wymieniono Michała Siedleckiego (napisał o ochronie wielorybów), Władysława Szafera (opisał niszczenie przyrody w procesie nieumiejętnego pozyskiwania roślin leczniczych), Adama Wodziczkę (autora artykułu poświęconego problematyce zieleni miejskiej w aspekcie ochrony przyrody).

Przedstawiano także zawartość publikacji książkowych (monografii) poświęconych problematyce ochrony przyrody, takich jak dzieło Mariana Sokołowskiego pt. Chrońmy przyrodę ojczysta i jej zabytki (Wydawnictwo Państwowej Komisji Ochrony Przyrody, 1924) poświęcone wyjaśnieniu motywów ochrony przyrody (historyczno-patriotyczny, estetyczny, przyrodniczo-naukowy, wychowawczy), obszarom/obiektom chronionym (parki natury, rezerwaty, zabytki i pomniki natury), sposobom ochrony przyrody oraz rozwoju ochrony przyrody na ziemiach polskich pod zaborami. Redaktorzy miesięcznika podkreślili, że to dzieło ze względu na walor dydaktyczno-wychowawczy powinno dotrzeć do najszerszego ogółu społeczeństwa

6 Przewodniczącym Komitetu Ochrony Przyrody w Poznaniu był prof. Adam Wodziczko. W jury konkursowym był również (m.in.) prof. Władysław Szafer - delegat Ministra Wyznań Religijnych i Oświecenia Publicznego do spraw Ochrony Przyrody. 
jako dostępne przede wszystkim w bibliotekach nauczycielskich, uczniowskich, harcerskich, wojskowych, turystycznych (Książki które warto czytać, 1925/1, s. 43).

Wiosną 1925 roku opisano projekt wydania Zielnika Tatrzańskiego (do użytku szkolnego) przez Muzeum Tatrzańskie im. T. Chałubińskiego w Zakopanem. Część pierwsza zielnika zawiera 50 rodzajów roślin luźno złożonych w 50 arkuszach półsztywnego papieru z drukowaną etykietą informacyjną zawierającą nazwę rośliny oraz miejsce i datę jej zbioru. Celem tej publikacji było zapobieganie masowemu niszczeniu roślinności górskiej podczas wycieczek szkolnych (Zawiadomienie..., 1925/4, S. 192).

Rekomendowano również inne publikacje (wydane staraniem Państwowej Rady Ochrony Przyrody). Egzemplifikację stanowi książka szwajcarskiego autora E. Riggenbacha pt. Jak może młodzież chronić przyrodę? (Wydawnictwo Państwowej Rady Ochrony Przyrody, nr 22, przetłumaczona na język polski przez M. Amouraux’a), przeznaczona dla dzieci i młodzieży. Dzieło zawiera wskazówki dotyczące ochrony przyrody w domu, na ulicy miast, na polach, w lesie i w wodzie. Ponieważ autor szczegółowo wyjaśnił sposoby ochrony ptaków zimą i latem, redaktorzy „Przyrody i Techniki” stwierdzili, że omawiane dzieło powinno być dostępne we wszystkich bibliotekach szkolnych, kółkach przyrodniczych oraz wśród harcerzy. Bardzo dobrym przykładem innej tego rodzaju publikacji jest książka Władysława Szafera pt. Parki Narodowe w Polsce - National Parks in Poland (wydawnictwo polsko-angielskie - Państwowej Rady Ochrony Przyrody, nr 23), w której prof. W. Szafer podał najważniejsze dane (wraz z mapami, zdjęciami danego krajobrazu, roślin i zwierząt) dotyczące już istniejących w Polsce obszarów chronionych oraz projektowanych lub będących w stanie realizacji polskich parków narodowych w Tatrach, Pieninach, Białowieży, Czarnohorze, Babiej Górze i w Górach Świętokrzyskich.

Poza tym na okładce (wewnętrznej) analizowanego miesięcznika umieszczano informacje ( $w$ formie reklamy) o książkach poświęconych problematyce ochrony przyrody. Egzemplifikację stanowi dzieło Władysława Szafera pt. Yellowstone. Kraj goracych źródet i niedźwiedzi, napisanej na podstawie osobistych przeżyć autora podczas podróży do Yellowstone. Polecano czytelnikom także publikację Zofii Gąsiorowskiej pt. Wrażenia $z$ Yellowstone Park. Notatki z podróży (zawarte są w niej zapiski z podróży zawierające m.in. opisy krajobrazu Gór Skalistych, gejzerów, zwierząt) (Gąsiorowska 1938/4, s. 193-201).

Napisano ponadto o publikacji pt. Obrazy roślinności Królestwa Polskiego, pod redakcją prof. Z. Wójcickiego (fotografie: R. Cholewiński, wydawanej od 1912 roku). Zaznaczono, że to dzieło nadal ukazuje się pod zmienionym tytułem: Krajobrazy roślinne Polski (ze zdjęciami innych autorów). Pisano o wartościowych książkach, np. J. S. Mikulskiego pt. Z zagadnień ekologii zwierząt (przeznaczona dla młodzieży szkolnej jako lektura pomocnicza) oraz J. Marchlewskiego pt. Zwierzęta ginace i ich ochrona - o szkodliwych skutkach gospodarki człowieka (książki wydane w ramach Biblioteki Biologicznej przez Książnicę - Atlas, Lwów-Warszawa). 


\section{Wystawy poświęcone opiece nad zwierzętami, ochronie przyrody}

W miesięczniku „Przyroda i Technika” opisano wystawę pt. Zwierzę w fotografii, zorganizowaną dzięki staraniu Związku Opieki nad Zwierzętami w Krakowie. Ekspozycja implikowała tysiąc twórczych ekspresji fotograficznych zwierzą domowych (psy, koty) i użytkowych (konie, bydło itp.) celem zjednania jak największej liczby zwolenników idei opieki nad zwierzętami. Eksponowano zdjęcia dokumentujące sytuacje źle traktowanych zwierząt (dręczonych, tresowanych). Poinformowano czytelników o wystawach pt. Nasze lasy oraz Ochrona przyrody. Można dodać, że wystawę poświęconą ochronie przyrody zorganizowano z inicjatywy Muzeum Przemysłu i Rolnictwa w Warszawie i Lwowskiej Izby Przemysłowo-Handlowej. Opisano działy (Parki Narodowe, Rezerwaty), w których przedstawiono przyrodę Tatr, Pienin, Babiej Góry, Czarnohory, Gór Świętokrzyskich, Puszczy Białowieskiej, Polesia i Wielkopolski. Zamieszczono także mapy i fotografie rezerwatów leśnych, stepowych, skalnych, jaskiniowych i wodnych (Wystawa Ochrony Przyrody, 1936/9, s. 550).

\section{Problematyka ochrony przyrody w „Metodyce biologii. Dodatku do czasopisma «Przyroda i Technika», poświęconym nauczaniu botaniki i zoologii” (wydawanym przez Zakłady Graficzne Spółki Akcyjnej Książnica Atlas we Lwowie) - edukacyjne implikacje}

Nauczyciele biologii na Zjeździe Kierowników Ognisk Metodycznych Biologii, który odbył się jesienią 1936 roku, zwrócili się do redakcji miesięcznika „Przyroda i Technika" z propozycją dalszego doskonalenia metod pracy w obszarze popularyzowania wiedzy przyrodniczej i ochrony przyrody. W tym celu zaproponowali, aby komitet redakcyjny przedmiotowego czasopisma kontynuował prowadzenie działów: laboratoryjnego, hodowlanego, ogrodu botanicznego, lektur pomocniczych, szlaków wycieczkowych, recenzji i ocen (Metodyka..., 1937/1, s. 1). Należy zaakcentować, że w ww. Dodatku... podjęto także problematykę ochrony przyrody. W maju 1937 roku opublikowano w nim interesujący artykuł Jadwigi Dyakowskiej, z którego wynika, że od 10 października 1935 roku minister wyznań religijnych i oświecenia publicznego, w porozumieniu z ministrem rolnictwa i reform rolnych, wydał rozporządzenie o uznaniu żółwia/Emys orbicularis L. za gatunek chroniony na całym obszarze Rzeczypospolitej. W związku z tym zabroniono zabijania żółwi, łowienia ich żywcem, podbierania lub niszczenia jaj żółwich. W myśl rozporządzenia minister wyznań religijnych i oświecenia publicznego mógł udzielać zezwoleń na łowienie żółwi dla celów naukowych, dydaktycznych lub hodowlanych. Jadwiga Dyakowska stwierdziła/założyła, że chociaż osoby zainteresowane hodowaniem żółwia błotnego w szkole mogą uzyskać takie specjalne pozwolenie ministra WRiOP, to jednak w sytuacji uznania żółwia za gatunek chroniony nie powinny hodować tego zwierzęcia w szkole (por. Dyakowska 1937/5, s. 80). 
Nauczycielka Stanisława Pawłowska, która była zatrudniona w gimnazjum im. E. Orzeszkowej w Tarnowie, na łamach Dodatku... opublikowała swój referat wygłoszony podczas Konferencji Ognisk Metodycznych Biologii w Krakowie, pt. Gazetka przyrodnicza ucznia. Zaakcentowała w nim, że według programu przyrody uczeń ma stać się „małym, ale poważnym badaczem przyrody” (Pawłowska 1937/6-7, s. 97), ma okazywać zainteresowanie lekturą przyrodniczą czy też problematyką ochrony przyrody. Jednym ze środków dydaktycznych prowadzących do tego celu może być wydawanie gazetki przyrodniczej w szkole, która powinna zmieniać się (jak to ujęła nauczycielka - „przechodzić ewolucje razem z uczniami”). Według Stanisławy Pawłowskiej pierwszym etapem przygotowania gazetki przyrodniczej jest zbieranie/gromadzenie materiału (np. z czasopism, dzienników, tygodników, w których pojawiają się aktualne wzmianki, artykuły). Dopiero na ich podstawie można kreować gazetkę przyrodniczą, „która będzie niejako afiszem propagandowym, zachęcającym do czytania” (Pawłowska 1937/6-7, s. 93). Układ gazetki ma motywować uczniów do czytania (artykuły krótkie napisane przez uczniów, estetyczna szata graficzna, wraz z ekspozycją wartościowych utworów literackich (Pawłowska 1937/6-7, s. 95).

Prezes Towarzystwa Popierania Ogródków Szkolnych, prof. Włodzimierz Gorjaczkowski, twierdził na łamach czasopisma, że Towarzystwo, szerząc wśród nauczycieli (od kilkunastu lat) ideę zakładania ogrodów szkolnych, postanowiło w 1937 roku założyć przykładowy ogród szkolny dla szkół powszechnych w Warszawie na terenie miejskiego Zakładu Hodowli Roślin (ul. Chodkiewicza 11), który odpowiada wymogom programu nauczania i który można stworzyć nawet dzięki skromnym środkom finansowym. Był to ogród podobny do prawdziwego, ale przystosowany do potrzeb szkoły powszechnej (Gorjaczkowski 1937/6-7, s. 97). W artykule autor zawarł uwagi dotyczące rozplanowania terenów szkolnych. Podkreślił, że zgodnie z programem nauczania w szkołach powszechnych (publicznych) każda szkoła posiadająca grunt (własny lub oddany do użytkowania) ma obowiązek prowadzić ogród szkolny i przeprowadzać w nim praktyczne zajęcia ogrodnicze w celu lepszego zrozumienia zasad życia w środowisku przyrody, w ekosystemie ogrodu.

Artykuł Włodzimierza Gorjaczkowskiego zawiera dane szczegółowe dotyczące wielkości ogrodu warzywnego oraz przeznaczonego na drzewa i krzewy owocowe, truskawki lub poziomki (Gorjaczkowski 1937/6-7, s. 100). Gorjaczkowski przedstawił także rysunek pt. Przykład urzadzenia ogrodu szkolnego na obszarze ok. $800 \mathrm{~m}^{2}$ (Gorjaczkowski 1937/6-7, s. 99). Znaczenie ogrodu szkolnego w procesie nauki szkolnej wyjaśnił także Franciszek Barański w artykule pt. Ogród szkolny (jego wykorzystanie w nauczaniu biologii w szkole średniej).

Można dodać, że w „Metodyce biologii. Dodatku do czasopisma Przyroda i Technika" (który jak już wspomniano był organem Ognisk Metodyki Biologii) napisano również na temat dydaktyki szczegółowej/metodyki szkolnych wycieczek przyrodniczych (Tołpa 1939/2-3, s. 17-38; Massalski 1939/2-3, s. 17-38). Podkreślano ich znaczenie w procesie kształcenia i wychowania do ochrony przyrody, czynnych 
postaw ekologicznych (Cholewa 1939/5, s. 65-88). Stwierdzono ponadto, że czasopismo „Przyroda i Technika” może służyć jako wartościowy środek dydaktyczny w procesie nauki szkolnej.

\section{Konkluzja}

Na podstawie jakościowej analizy źródła drukowanego: miesięcznika „Przyroda i Technika" (1922-1939) potwierdzono tezę dotyczącą edukacyjnego waloru ochrony przyrody. W przedmiotowym czasopiśmie, wydawanym w Rzeczypospolitej $\mathrm{w}$ okresie dwudziestolecia międzywojennego drukowano na ten temat artykuły. W związku z powyższym można dodać, że proces dydaktyczno-wychowawczy rozwijający czynne postawy ekologiczne, realizowany w Polsce $\mathrm{w}$ drugiej połowie XX oraz w XXI wieku, jest zakorzeniony w edukacyjnym dziedzictwie kulturowym, a jego egzemplifikację stanowi twórczość autorska prezentowana w analizowanym periodyku. Stanowi ona bowiem kulturową kontynuację idei oraz działań aplikacyjnych w dziedzinie ochrony przyrody.

\section{Bibliografia}

Cholewa S. Las jako zbiorowisko (elementy wycieczki w II kl. gimnazjalnej). W: „Metodyka biologii. Dodatek do czasopisma Przyroda i Technika” (Organ Ognisk Metodyki Biologii), 1939 (rok 3), z. 5 (maj), s. 65-88.

Co się dzieje w Polsce? Przepisy dla zwiedzajacych Park Narodowy im. Żeromskiego w „Puszczy Jodłowej”. W: „Przyroda i Technika” (Czasopismo poświęcone popularyzacji nauk przyrodniczych i technicznych. Wychodzi raz na miesiąc Z wyjątkiem lipca i sierpnia), 1933 (rocznik 12), z. 8 (wrzesień), s. 367-368.

Dunajewski A. O kilku gatunkach zwierząt wymierajacych i wymarlych. W: „Przyroda i Technika” (Miesięcznik poświęcony naukom przyrodniczym i ich zastosowaniu. Wydawany przez Polskie Towarzystwo Przyrodników im. M. Kopernika, 1930 (rocznik 9), z. 8 (październik), s. 337-347.

Dyakowska J. Ochrona przyrody w szkole. W: „Metodyka biologii. Dodatek do czasopisma Przyroda i Technika poświęcony nauczaniu botaniki i zoologii” 1937, (rok 1), z. 5, s. 8 o.

Dyakowski B. O skutkach nieracjonalnego użytkowania lasu. W: „Przyroda i Technika" (Czasopismo poświęcone popularyzacji nauk przyrodniczych i technicznych), 1938 (rocznik 17), z. 5 (maj), s. 271-277.

Fuliński B. Marjan Raciborski. W: „Przyroda i Technika” (Miesięcznik poświęcony naukom przyrodniczym i ich zastosowaniu, wydawany przez Polskie Towarzystwo Przyrodników im. M. Kopernika), 1923 (rocznik 2), z. 4 (kwiecień), s. $205-210$. 
Gąsiorowska Z. Wrażenia z Yellowstone Park. Notatki z podróży. W: „Przyroda i Technika” (Czasopismo poświęcone popularyzacji nauk przyrodniczych i technicznych), 1938 (rocznik 17), z. 4 (kwiecień), s. 193-201.

Ginace drzewo. W: „Przyroda i Technika” (Miesięcznik poświęcony naukom przyrodniczym i ich zastosowaniu, wydawany przez Polskie Towarzystwo Przyrodników im. M. Kopernika), 1924 (rocznik 3), z. 3-4 (marzec - kwiecień), S. $243-246$.

Gorjaczkowski W. Przewodnik po przykładowym ogrodzie szkolnym założonym na terenie Zakładu Hodowli Roślin m. st. Warszawy, przy ul. Chodkiewicza 11. W: „Metodyka biologii. Dodatek do czasopisma «Przyroda i Technika», poświęcony nauczaniu botaniki i zoologii" 1937, (rok 1), z. 6/7, s. 97.

Jaranowska I. Plaga pyłu i dymu w miastach. W: „Przyroda i Technika” (Miesięcznik poświęcony naukom przyrodniczym i ich zastosowaniu. Wydawany przez Polskie Towarzystwo Przyrodników im. M. Kopernika. Bydgoszcz-Kraków-Lwów-Poznań-Sosnowiec-Warszawa-Wilno), 1927 (rocznik 6), z. 9 (listopad), s. 405-418.

Jarmolińska H. Życie lasu w zimie. Nasze porosty. W: „Przyroda i Technika” (Czasopismo poświęcone popularyzacji nauk przyrodniczych i technicznych), 1935 (rocznik 14), z. 1 (styczeń), s. 1-8.

Keler S. Ochrona przyrody ze stanowiska pierwotnego i kulturalnego. W: „Przyroda i Technika” (Czasopismo poświęcone popularyzacji nauk przyrodniczych i technicznych. Wychodzi raz na miesiąc z wyjątkiem lipca i sierpnia), 1934 (rocznik 13), z. 5 (maj), s. 193-196.

Keler S. Przy karmiku. W: „Przyroda i Technika” (Czasopismo poświęcone popularyzacji nauk przyrodniczych i technicznych. Wychodzi raz na miesiąc Z wyjątkiem lipca i sierpnia), 1934 (rocznik 13), z. 9 (listopad), s. 409-415.

Klimowicz W. Nowe badania nad klimatem. W: „Przyroda i Technika” (Miesięcznik poświęcony naukom przyrodniczym i ich zastosowaniu. Wydawany przez Polskie Towarzystwo Przyrodników im. M. Kopernika. Bydgoszcz-KrakówLwów-Poznań-Sosnowiec-Warszawa-Wilno), 1927 (rocznik 6), z. 9 (listopad), S. $425-427$.

Krzemieniewski S. Ochrona przyrody ojczystej i jej znaczenie. Z posiedzenia Lwowskiej Kuratorji Ochrony Przyrody dnia 24 lutego 1922. W: „Przyroda i Technika” (Miesięcznik poświęcony naukom przyrodniczym oraz rozwojowi przemysłu i rolnictwa, wydawany przez Polskie Towarzystwo Przyrodników im. M. Kopernika. Kraków-Lwów-Poznań-Warszawa-Wilno), 1922 (rocznik 1), Z. 1 (październik), s. 23-27.

Krzemieniewski S. Ochrona przyrody ojczystej i jej znaczenie. Z posiedzenia Lwowskiej Kuratorji Ochrony Przyrody, dnia 24 lutego 1922 [ciag dalszy]. W: „Przyroda i Technika” (Miesięcznik poświęcony naukom przyrodniczym oraz rozwojowi przemysłu i rolnictwa, wydawany przez Polskie Towarzystwo 
Przyrodników im. M. Kopernika. Kraków-Lwów-Poznań-Warszawa-Wilno), 1922 (rocznik 1), z. 2 (listopad), s. 95-96.

Książki które warto czytać. W: „Przyroda i Technika” (Miesięcznik poświęcony naukom przyrodniczym i ich zastosowaniu. Wydawany przez Polskie Towarzystwo Przyrodników im. M. Kopernika. Bydgoszcz-Kraków-LwówPoznań-Warszawa-Wilno), 1925 (rocznik 4), z. 1 (styczeń), s. 43.

Kuntze R. Wpływ człowieka na skład fauny. W: „Przyroda i Technika” (Miesięcznik poświęcony naukom przyrodniczym i ich zastosowaniu. Wydawany przez Polskie Towarzystwo Przyrodników im. M. Kopernika. Bydgoszcz-KrakówLwów-Poznań-Warszawa-Wilno), 1926 (rocznik 5), z. 10 (grudzień), s. 451-458.

Kuntze R. Z rozważań nad podstawowemi zasadami ekologii zwierząt. W: „Przyroda i Technika” (Czasopismo poświęcone popularyzacji nauk przyrodniczych i technicznych. Wychodzi raz na miesiąc z wyjątkiem lipca i sierpnia), 1934 (rocznik 13), z. 5 (maj), s. 197-208.

Kuntze R. Żubr białowieski i żubr kaukaski w oświetleniu systematyki podgatunkowej. W: „Przyroda i Technika” (Czasopismo poświęcone popularyzacji nauk przyrodniczych i technicznych), 1935 (rocznik 14), z. 18 (grudzień), s. 448-455.

Lindeman W. Ochrona zwierząt w parkach natury a gospodarka łowiecka. W: „Przyroda i Technika” (Czasopismo poświęcone popularyzacji nauk przyrodniczych i technicznych), 1937 (rocznik 16), z. 3 (marzec), s. 139-140.

Massalski E. Wycieczki biologiczne w Góry Świętokrzyskie. W: „Metodyka biologii. Dodatek do czasopisma "Przyroda i Technika»" (Organ Ognisk Metodyki Biologii), 1939 (rok 3), z. 2-3 (luty - marzec), s. 17-38.

„Metodyka biologii. Dodatek do czasopisma «Przyroda i Technika» poświęcony nauczaniu botaniki i zoologii" 1937, (rok 1), z. 1, s. 1.

Niementowski S. Do Czytelników. W: „Przyroda i Technika” (Miesięcznik poświęcony naukom przyrodniczym oraz rozwojowi przemysłu i rolnictwa, wydawany przez Polskie Towarzystwo Przyrodników im. M. Kopernika. Kraków-LwówPoznań-Warszawa-Wilno), 1922 (rocznik 1), z. 1 (październik), s. 1, 3.

Nowoczesne zużytkowanie śmieci. W: „Przyroda i Technika” (Miesięcznik poświęcony naukom przyrodniczym i ich zastosowaniu. Wydawany przez Polskie Towarzystwo Przyrodników im. M. Kopernika, 1928 (rocznik 7), z. 4 (kwiecień), s. $184-185$.

Ochrona przyrody w Polsce. W: „Przyroda i Technika” (Miesięcznik poświęcony naukom przyrodniczym i ich zastosowaniu. Wydawany przez Polskie Towarzystwo Przyrodników im. M. Kopernika, 1929 (rocznik 8), z. 5 (maj), s. 220.

O wprowadzeniu ochrony przyrody do nauczania szkolnego. W: „Przyroda i Technika” (Miesięcznik poświęcony naukom przyrodniczym i ich zastosowaniu. Wydawany przez Polskie Towarzystwo Przyrodników im. M. Kopernika. Bydgoszcz-Kraków-Lwów-Poznań-Warszawa-Wilno), 1926 (rocznik 5), z. 4 (kwiecień), s. 190-191. 
Paczoski J. Roślina i siedlisko. W: Przyroda i Technika" (Czasopismo poświęcone popularyzacji nauk przyrodniczych i technicznych), 1937 (rocznik 16), z. 8 (październik), s. 449-457.

Pawłowska S. Gazetka przyrodnicza ucznia. W: „Metodyka biologii. Dodatek do czasopisma Przyroda i Technika poświęcony nauczaniu botaniki i zoologii" 1937, (rok 1), z. 6/7, s. 92.

Przegląd czasopism. W: „Przyroda i Technika” (Miesięcznik poświęcony naukom przyrodniczym i ich zastosowaniu. Wydawany przez Polskie Towarzystwo Przyrodników im. M. Kopernika. Bydgoszcz-Kraków-Lwów-PoznańWarszawa-Wilno), 1925 (rocznik 4), z. 1 (styczeń), s. 92-94.

Przegląd czasopism. W: „Przyroda i Technika” (Miesięcznik poświęcony naukom przyrodniczym i ich zastosowaniu. Wydawany przez Polskie Towarzystwo Przyrodników im. M. Kopernika. Bydgoszcz-Kraków-Lwów-PoznańWarszawa-Wilno), 1925 (rocznik 4), z. 10 (grudzień), s. 489.

Pazdro Z. Polskie Zagłębie Węglowe pod względem geologicznym. W: „Przyroda i Technika" (Miesięcznik poświęcony naukom przyrodniczym i ich zastosowaniu. Wydawany przez Polskie Towarzystwo Przyrodników im. M. Kopernika. Bydgoszcz-Kraków-Lwów-Poznań-Warszawa-Wilno), 1925 (rocznik 4), z. 10 (grudzień), s. 441-448.

Ruch naukowy. Z dorocznych obrad Państwowej Rady Ochrony Przyrody. (1933). W: „Przyroda i Technika” (Czasopismo poświęcone popularyzacji nauk przyrodniczych i technicznych. Wychodzi raz na miesiąc z wyjątkiem lipca i sierpnia), 1933 (rocznik 12), z. 4 (kwiecień), s. 186-187.

Sokołowski M. Las w walce o byt. W: Przyroda i Technika" (Czasopismo poświęcone popularyzacji nauk przyrodniczych i technicznych), 1937 (rocznik 16), z. 6 (czerwiec), s. 321-334.

Strawiński K. Zwalczanie szkodników i ochrona roślin w Polsce. W: „Przyroda i Technika" (Miesięcznik poświęcony naukom przyrodniczym i ich zastosowaniu. Wydawany przez Polskie Towarzystwo Przyrodników im. M. Kopernika, 1929 (rocznik 8), z. 8 (październik), s. 348-356.

Szafer W. Co się dzieje w Polsce. Roślinom lekarskim grozi wytępienie. W: „Przyroda i Technika" (Czasopismo poświęcone popularyzacji nauk przyrodniczych i technicznych. Wychodzi raz na miesiąc z wyjątkiem lipca i sierpnia), 1931 (rocznik 10), z. 5 (maj), s. 236-239.

Tołpa S. Wycieczki przyrodnicze w kl. II gimnazjum. W: „Metodyka biologii. Dodatek do czasopisma Przyroda i Technika" (Organ Ognisk Metodyki Biologii), 1938 (rok 2), z. 10 (grudzień), s. 133-138.

Wodziczko A. Gatunki roślin chronione na całym obszarze Rzeczypospolitej. W: „Przyroda i Technika” (Czasopismo poświęcone popularyzacji nauk przyrodniczych i technicznych), 1936 (rocznik 15), z. 3 (marzec), s. 167-168. 
Wodziczko A. Kierunki współczesnej ochrony przyrody. W: „Przyroda i Technika” (Czasopismo poświęcone popularyzacji nauk przyrodniczych i technicznych), 1935 (rocznik 14), z. 4 (kwiecień), s. 145-148.

Wystawa Ochrony Przyrody. W: „Przyroda i Technika” (Czasopismo poświęcone popularyzacji nauk przyrodniczych i technicznych), 1936 (rocznik 15), z. 9 (listopad), s. 550.

Zawiadomienie. „Zielnik Tatrzański”. W: „Przyroda i Technika” (Miesięcznik poświęcony naukom przyrodniczym i ich zastosowaniu. Wydawany przez Polskie Towarzystwo Przyrodników im. M. Kopernika.Bydgoszcz-Kraków-LwówPoznań-Warszawa-Wilno), 1925 (rocznik 4), z. 4 (kwiecień), s. 192.

Z ochrony przyrody. W: „Przyroda i Technika” (Miesięcznik poświęcony naukom przyrodniczym i ich zastosowaniu, wydawany przez Polskie Towarzystwo Przyrodników im. M. Kopernika), 1923 (rocznik 2), z. 5 (maj), s. 297-302.

\title{
ENVIRONMENTAL PROTECTION OF THE FATHERLAND IN THE SECOND REPUBLIC OF POLAND - EDUCATIONAL IMPLICATIONS OF THE MONTHLY “PRZYRODA I TECHNIKA"
}

\begin{abstract}
Abstact: The purpose of this article is to explain the cultural heritage based on the example of education for environmental protection in Poland in the period between the two world wars (1918-1939). The main source is the periodical "Przyroda i Technika", issued by M. Copernicus Polish Association of Environmentalists between 1922 and1939. The article justifies the meaning of the process of education for environmental protection of the Polish society by analising selected articles and educational competitions, exhibitions dedicated to the issue of animal care, as well as popularization of books and periodicals dedicated to environmental protection.
\end{abstract}

Keywords: history of education; "Przyroda i Technika"; environmental protection; education for ecological attitudes.

Edyta Wolter - doktor habilitowana, pedagog - historyk edukacji, profesor nadzwyczajna w Katedrze Historii Wychowania i Dziejów Oświaty na Wydziale Nauk Pedagogicznych Uniwersytetu Kardynała Stefana Wyszyńskiego w Warszawie. Członkini Towarzystwa Uniwersyteckiego „Fides et Ratio”, Zespołu Pedagogiki Chrześcijańskiej, działającego pod Patronatem Komitetu Nauk Pedagogicznych Polskiej Akademii Nauk (status członka rzeczywistego Zespołu), Towarzystwa Historii Edukacji (THE). Autorka 185 publikacji naukowych, w tym sześciu książek autorskich. Zainteresowania naukowe, główne kierunki badań naukowych: kulturowe uwarunkowania edukacji ekologicznej, pedagogiczne aspekty zrównoważonego rozwoju w środowisku społeczno-przyrodniczym, pedagogiczne implikacje ekologii człowieka, pedagogika ekologiczna, historyczne aspekty edukacji ekologicznej w Polsce, edukacja ekologiczna w II Rzeczypospolitej (1918-1939), edukacja ekologiczna dzieci. Adres e-mailowy: e.wolter@uksw.edu.pl. 